\title{
Pengaruh Budaya, Karakteristik Dan Motivasi Terhadap Intensi Berwirausaha Serta Dampaknya Pada Startup Usaha Mahasiswa Di Kota Pekanbaru
}

\author{
BAMBANG SUROTO \\ Universitas Lancang Kuning \\ Jln. Yos Sudarso Km 08 Rumbai Telp. (0761) 52581 Fax. (0761) 52581 \\ E-mail : bambangsuroto@unilak.ac.id
}

\begin{abstract}
Wujud nyata dalam belajar kewirausahaan adalah munculnya intensi berwirausaha atau minat berusaha di kalangan mahasiswa. Namun dari pra survey yang dilakukan hanya sekitar kurang dari 5\% mahasiswa yang berminat berwirausaha. Tentunya terdapat banyak faktor penyebab dilihat dari itu faktor dalam (internal) maupun faktor luar (eksternal) mahasiswa. Jadi penelitian ini ingin mengetahui model determinan intensi wirausaha mahasiswa. Informasi ini penting diketahui karena sebagai dasar evaluasi dalam rangka pengembangan wirausaha muda mahasiswa. Penggunaan sintesa dari berbagai teori intensi berwirausaha mahasiswa dan pengujian hipotesis dari teori yang digunakan menjadi dasar penelitian model ini. Metode kuantitatif dengan pendekatan survey digunakan dalam penelitian ini. Data dikumpulkan dari populasi mahasiswa program studi manajemen pada semester akhir dengan sampel diambil sebanyak 88 orang. Pengumpulan data dengan menggunakan kuesioner online dan teknik analisis data dengan menggunakan teknik analisis kuantitatif dengan alat analisis model struktur dengan dukungan software WarpPLS. Hasil penelitian menunjukkan bahwa menunjukkan bahwa keinginan untuk memulai usaha (intensi berwirausaha) bagi mahasiswa terbukti disebabkan oleh budaya belajar, karakteristik individu dan juga pemberian motivasi. Dari ketiga variabel tersebut kontribusinya sebesar 54\%. Kemudian juga variabel karakteristik individu merupakan menjadi lebih dominan apabila dibandingkan dengan variabel budaya belajar dan pemberian motivasi. Intensi berwirausaha juga berpengaruh signifikan terhadap startup usaha yang dilakukan oleh mahasiswa tersebut yakni sebesar $39 \%$.
\end{abstract}

Kata Kunci : Intensi Berwirausaha Mahasiswa, Budaya Belajar, Karakteristik Individu, Pemberian Motivasi, Startup Usaha.

Kewirausahaan menjadi bagian penting dalam rangka mengatasi berbagai persoalan ekonomi yang ada dalam sebuah Negara. Melalui pengembangan kewirausahaan, banyak manfaat diperoleh diantaranya adanya perkembangan produk kreatifitas yang dihasilkan wirausahawan dan juga terciptanya lapangan pekerjaan yang menjadi bagian penting dan juga solusi bagi pemerintah dalam rangka mengurangi angka pengangguran. Kemudian juga masalah daya saing bangsa yang dengan wirausahawan generasi muda dapat menjadi bangsa yang mandiri dengan tingkat daya saing yang tinggi.

Kemampuan sebuah bangsa untuk bertahan dan tumbuh berkembang menjadi Negara yang berdaulat dan bangsa yang mandiri menjadi sebuah cita-cita berdirinya sebuah bangsa. Bangsa yang memiliki sumberdaya manusia yang handal dengan kreatifitasnya menghasilkan inovasi sangat membantu dalam mewujudkan keinginan bangsa dan juga sangat menjadi solusi dari berbagai masalah yang dihadapi sebuah bangsa. Bahkan sebagaimana bangsa Indonesia saat ini sudah menjadikan kajian kewirausahaan menjadi kajian strategis untuk diprioritaskan guna mencapai apa yang diharapkan.

Perguruan tinggi sebagai salah satu agen perubahan bangsa menjadikan para generasi penerus bangsa menimba ilmu dan pengetahuan serta teknologi guna siap menghadapi persaingan yang ketat dengan bangsa lain. Perguruan tinggi dengan berbagai keunikannya dan sumber daya 
yang mampu menjawab berbagai persoalan yang dihadapi bangsa, akan menjadikan perguruan tinggi sebagai lembaga yang strategis merubah cara pandang generasi muda.

Generasi muda yang aktif dan juga reaktif terhadap dinamika kehidupan dengan berbagai kondisi yang ada dan bahkan melalui berbagai guncangan masa depan juga siap untuk dihadapinya. Generasi muda membutuhkan nutrisi pengetahuan, kemampuan berpikir kritis, ketrampilan hidup dan juga berbagai kebutuhan sikap dan prilaku yang seharusnya mereka akan dapatkan di lembaga pendidikan. Generasi muda berupa mahasiswa adalah generasi muda terkini yang siap bersaing menghadapi kondisi nyata di masa depan.

Persaingan yang ketat pada dunia usaha menjadikan lembaga perguruan tinggi harus bersinerji dengan selalu menyusun kurikulum yang siap untuk menghadapi bebagai keadaan yang dibutuhkan di masa depan. Sinerji dengan dunia bisnis, sinerji dengan orang tua dan sinerji dengan mahasiswa serta pemerintah menjadikan lembaga perguruan tinggi dapat menawarkan menu yang unik bagi mahasiswa. Persiapan lembaga tersebut dengan matang dipersiapkan, mulai dari tenaga pendidik yang berpengalaman dan juga berpengetahuan dibidangnya ditambah dengan fasilitas penunjang pendidikan dan sistem pendidikan yang siap pakai dan juga berbagai dukungan kerjasama dengan dunia usaha akan menjadikan lembaga dapat menjawab persoalan masa depan.

Sebagaimana yang dipersiapkan oleh Prodi Manajemen Universitas Lancang Kuning. Saat ini dengan pengembangan kurikum berbasis KKNI dan dengan bersinerji dengan dunia usaha dan juga memiliki learning outcome wirausaha muda dan manajer lini pertama menjadikan Prodi Manajemen selalu harus mengevaluasi diri, melihat perkembangan mahasiswa dan juga selalu memahami kendala yang dialami dan juga melakukan perbaikan dari masa ke masa.
Permasalahan intensi berwirausaha mahasiswa semester lima dan tujuh, dimana mahasiswa yang sudah diberikannya berbagai pengetahuan dan juga ketrampilan serta motivasi berwirauaha, sudah semestinya menghasilkan mahasiswa yang memiliki intensi berwirausaha yang tinggi. Namun dari hasil pra survey yang dilakukan kepada 30 orang mahasiswa, diketahui bahwa kurang dari 5\% mahasiswa Prodi. Manajemen memiliki intensi yang tinggi dalam berwirausaha. Sedangkan sisanya mahasiswa masih ragu dan bahkan kurang berminat untuk berwirausaha.

Terdapat banya faktor determinan
intensi berwirausaha mahasiswa, diantaranya sebagaimana disampaikan oleh Nurmansyah (2017) bahwa faktor pendidikan dan motivasi; kemudian juga dikatakan oleh Andika, M., \& Madjid, I. (2012) bahwa faktor sikap mahasiswa dalam belajar, norma subjektif dan efikasi diri. Juga disampaikan oleh Astuti, D. A. W. (2009) bahwa faktor konteks keluarga, pekerjaan, pendidikan, hambatan dan dukungan sosial, nilai-nilai individualism serta kolektifitas mempengaruhi intensi berwirausaha mahasiswa. Selain itu juga disampaikan oleh Srimulyani, V. (2013) bahwa kecerdasan adversitas dan juga berkaitan dengan internal locus of control serta karir yang matang turut mempengaruhi intensi untuk berwirausaha bagi mahasiswa.

Berangkat dari pendapat terebut, maka dalam penelitian ini apabila dilihat dengan model pembelajaran berbasis budaya melayu, maka apakah hal ini memberikan pengaruh pada intensi berwirausaha. Faktor nilai budaya, faktor karakteristik individu dan faktor pemberian motivasi apakah mempengaruhi intensi berwirausaha bagi mahasiswa dan apakah hal tersebut berdampak pada mahasiswa memulai berwirausaha.

Uraian mengenai intensi berwirausaha dapat dilihat dari berbagai pendapat ahli sebagai berikut: Menurut 
Astuti, D. A. W. (2009) intensi berwirausaha merupakan sebuah keterarikan seseorang dalam hal-hal kewirausahaan. Ini menjukkan bahwa intensitas seorang dalam mana seseorang tampak tertarik untuk melakukan kegiatan berwirausaha. Kegiatan ini menjadi sebuah usaha untuk mencari keuntungan dan tertarik untuk mempelajari bagaimana mendapatkan keuntungan. Kemudian disampaikan pula oleh

Kemudian menurut Handaru (2015) bahwa intensi berwirausaha merupakan sebuah keinginan untuk memulai sebuah usaha. Kemudian tolok ukur atau dimensi variabel intensi berwirausaha menurut Vemmy (2013) terdiri dari empat dimensi pertama desires (keinginan yang tinggi untuk memulai usaha), kedua preferences (kemandirian), ketiga plans (perencanaan) dan keempat behavior expectancies (semangat memulainya).

Terdapat banyak penyebab intensi berwirausaha sebagaimana disampaikan oleh Nurmansyah (2017) bahwa faktor pendidikan dan motivasi; kemudian juga dikatakan oleh Andika, M., \& Madjid, I. (2012) bahwa faktor sikap mahasiswa dalam belajar, norma subjektif dan efikasi diri. Juga disampaikan oleh Astuti, D. A. W. (2009) bahwa faktor konteks keluarga, pekerjaan, pendidikan, hambatan dan dukungan sosial, nilai-nilai individualism serta kolektifitas mempengaruhi intensi berwirausaha mahasiswa.

Selain itu juga disampaikan oleh Srimulyani, V. (2013) bahwa kecerdasan adversitas dan juga berkaitan dengan locus of control; juga karir yang matang yang ikut mempengaruhi intensi dalam berwirausaha mahasiswa. Astuti, D. A. W. (2009) menyatakan bahwa intensi berwirausaha berdampak pada starup usaha yang dilakukan mahasiswa.

Menurut Andika, M., \& Madjid, I. (2012) norma subjektif sebagai bentuk budaya dalam belajar. Universitas Lancang Kuning menerapkan tujuh nilai unilak yakni: religius, jujur, disiplin, visioner, bertanggungjawab, bermartabat, kerjasama.

\section{METODE}

Penelitian jenis kuantitatif digunakan yakni jenis penelitian yang melakukan uji hipotesis penelitian dengan menggunakan hipotesis statistik sebagai bahan penguji yang ada. Data yang digunakan berbentuk data primer dan data skunder, dapat dilihat dari uraian berikut ini: Data primer, yakni berisikan data bersumber dari responden penelitian diantaranya dapat tanggapan responden tentang penerapan budaya belajar, karakteristik individu, pemberian motivasi berwirausaha dan intensi berwirausaha serta starup usaha. Data sekunder, berisikan data yang berasal dari Prodi. Manajemen berkaitan dengan perkembangan jumlah mahasiswa dan juga gambaran mahasiswa.

Penelitian ini menggunaan objek penelitian adalah mahasiswa aktif program studi manajemen (S1) semester V dan VII Universitas Lancang Kuning, dengan jumlah 710 orang. Sampel diambil sebanyak 88 orang secara cluster random sampling yakni berdasarkan tingkatan. Penghitungan sampel dengan menggunakan rumus slovin.

$$
\begin{aligned}
& \text { Perhitungan Sampel: } \\
& \mathrm{n}=710 / 710 \times 10 \%^{2}+1 \\
& \mathrm{n}=710 / 8,10 \\
& \mathrm{n}=88
\end{aligned}
$$

Penelitian ini dilakukan di Prodi Manajemen (S1) Universitas Lancang Kuning, teknik kuesioner digunakan untk pengumpulan data. Penelitian ini menggunakan metode kuantitatif. Pengolahan data dimulai dari memperhitungkan secara deskriptif masing-masing variabel penelitian. Jawaban responden diberikan skore dengan menjumlahkan perkalian bobot masing-masing jawaban dengan frekuensi jawaban responden lalu dibagi dengan sampel penelitian. Sedangkan teknik analisis data dengan menggunakan teknik model struktur SEM dengan dukungan software WarpPLS. 


\section{HASIL}

Berdasarkan hasil survey secara online yang dilaksanakan kepada mahasiswa semester V dan VII program studi manajemen diperoleh informasi berkenaan data penelitian yang sebelumnya sudah dilakukan uji validitas dan uji reliabilitasnya dan uji normalitas datanya (lihat lampiran), maka dapat diketahui deskripsi data penelitian sebagai berikut:

\section{Deskripsi Variabel Penelitian}

Uraian berkenaan dengan variabel penelitian dapat dilihat dari variabel intensi berwirausaha, kemudian budaya belajar, karakteristik individu, pemberian motivasi kepada mahasiswa dan juga startup usaha. Jawaban responden terhadap variabel intensi berwirausaha 4,248 yang bermakna sangat baik. Ini menunjukkan bahwa pada dasarnya intensi berwirausaha mahasiswa manajemen untuk memulai usahanya sangat tinggi. Dari lima item yang ditanyakan ternyata item tertinggi jatuh pada Selalu memiliki rasa ingin tahu yang tinggi setiap melihat seseorang berhasil dalam bisnisnya. Sedangkan item terendah jatuh pada Memiliki pengetahuan terhadap ciri sebuah produk dalam bisnis.

Kemudian jawaban responden terhadap variabel budaya belajar mahasiswa Program studi manajemen, dapat diketahui bahwa budaya belajar mahasiswa dalam belajar kewirausahaan dengan bobot 4,407 masuk dalam kategori sangat baik. Dimana mahasiswa memiliki semangat yang tinggi dalam belajar kewirausahaan. Dari 7 item yang ditanyakan dapat diketahui bahwa item tertinggi terletak pada memiliki cita-cita yang jelas di masa depan dan item terendah terletak pada selalu berdiskusi dengan teman dalam menyelesaikan masalah.

Selanjutnya tanggapan responden terhadap variabel karakteristik individu yang dimiliki mahasiswa, dapat diketahui bahwa jawaban responden terhadap karakteristik individu yang dimiliki mahasiswa dengan rata-rata skor 3,867, masuk dalam kategori baik. Ini menunjukkan bahwa mahasiswa sudah memiliki karakter yang mendukung mereka untuk berwirausaha. Dari 3 item yang ditanyakan dapat diketahui bahwa jawaban tertinggi terletak pada merasa memiliki bakat dalam bidang bisnis sedangkan jawaban terendah terletak pada memiliki pengalaman dalam berbisnis.

Dilanjutkan pada variabel pemberian motivasi, dapat dilihat dari uraian bahwa jawaban responden dengan rata-rata skor seesar 4,636 dikategorikan sangat baik. Ini menunjukkan bahwa pemberian motivasi dari program studi manajemen seperti dalam kegiatan perkuliahan dan juga kesempatan untuk mengembangkan diri dalam bidang kewirausahaan juga diberikan kepada mahasiswa.

Berkenaan dengan variabel pemberian motivasi dengans kot 4,621 masuk dalam kategori sangat baik dan ini apabila dilihat dari 3 item yang ditanyakan item tertinggi adalah pada merasa senang bila keberhasilan dicapai adalah jeriah payah diri sendiri sedangkan item terendah adalah pada merasa senang dengan sebuah kemandirian.

Terakhir deskripsi tentang variabel startup usaha mahasiswa, dari jawaban responden, dapat diketahui bahwa jawaban responden terhadap startup usaha yang dijalankan dengan skor 4,173 dikategorikan baik, bahwa pada dasarnya mahasiswa manajemen sudah memiliki memulai untuk menjalankan usahanya. Dari 4 item yang ditanyakan dapat diketahui bahwa item tertinggi terletak pada memiliki semangat yang tinggi untuk berbisnis, sedangkan terendah adalah pada memiliki rencana bisnis yang siap dijalankan. 


\section{Analisis Pengaruh Budaya Belajar Karakteristik Individu dan Pemberian Motivasi Terhadap Intensi Berwirausaha Mahasiswa dan Dampaknya pada Startup Usaha Mahasiswa}

Dari hasil analisis data dengan menggunakan alat analisis SEM, dan data diolah dengan mengguankan software WarpPLS, maka dapat full model penelitian yang diuraikan dari gambar di bawah ini:

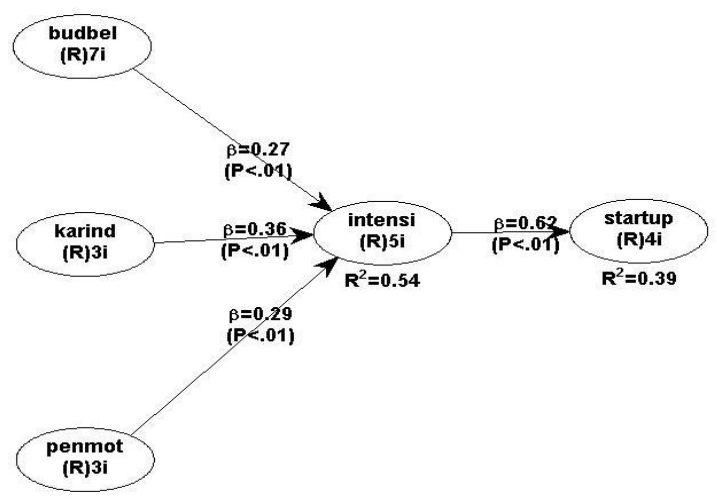

Gambar 1:

Full Model Pengaruh Budaya Belajar Karakteristik Individu dan Pemberian Motivasi Terhadap Intensi Berwirausaha Mahasiswa dan Dampaknya pada Startup Usaha Mahasiswa

Dari gambar tersebut, dapat dilihat bahwa nilai signifikansi seluruh variabel memiliki nilai $\mathrm{P}<0,01$ ini membuktikan bahwa seluruh variabel memberikan pengaruh nyata pada intensi mahasiswa berwirausaha dan juga terhadap startup usaha. Variabel keinginan untuk memulai usaha (intensi berwirausaha) bagi mahasiswa terbukti disebabkan oleh budaya belajar, karakteristik individu dan juga pemberian motivasi. Dari ketiga variabel tersebut kontribusinya sebesar $54 \%$. Kemudian juga variabel karakteristik individu lebih dominan bila dibandingkan dengan variabel budaya belajar dan pemberian motivasi. Intensi berwirausaha juga berpengaruh signifikan terhadap startup usaha yang dilakukan oleh mahasiswa tersebut yakni sebesar 39\%.

\section{PEMBAHASAN}

Berdasarkan uraian data hasil penelitian dapat diketahui bahwa dari pengaruh variabel budaya belajar terhadap intensi berwirausaha memiliki pengaruh yang signifikan dimana pada dasarnya intensi berwirausaha mahasiswa manajemen untuk memulai usahanya sangat tinggi, semakin baik budaya belajar maka semakin tinggi pula intensi berwirausaha mahasiswa. Mahasiswa memiliki semangat yang tinggi dalam belajar kewirausahaan. Dari 7 item yang ditanyakan dapat diketahui bahwa item tertinggi terletak pada memiliki cita-cita yang jelas di masa depan. Semakin baik cita-cita yang dimiliki mahasiswa maka mahasiswa aan memiliki rasa ingin tahu yang tinggi setiap melihat seseorang berhasil dalam bisnisnya. Begitu pula sebaliknya semakin rendah cita-cita yang dimiliki maka keinginannya untuk berusaha semakin rendah pula.

Selanjutnya dilihat dari variabel karateristik individu mahasiswa dapat diketahui bahwa memiliki pengaruh positif dan signifikan, mahasiswa sudah memiliki karakter yang mendukung mereka untuk berwirausaha. Dari 3 item yang ditanyakan dapat diketahui bahwa jawaban tertinggi terletak pada merasa memiliki bakat dalam bidang bisnis sedangkan jawaban terendah terletak pada memiliki pengalaman dalam berbisnis. Karakteristik memberikan gambaran akan kesungguhannya untuk melakukan banyak hal dengan belajar sendiri dan terus berusaha mendapatkan pengetahuan yang seharusnya mereka dapatkan. Pengetahuan tersebut dijadikan sebagai bekal untuk membangun usaha yang akan datang.

Pada variabel pemberian motivasi dari lembaga perguruan tinggi juga berpengaruh positif dan signifikan dimana semakin baik pemberian motivasi kepada mahasiswa untuk berwirausaha maka akan semakin tinggi pula keinginannya untuk berusaha. Pengaruh yang siginifikan ini terutama pada itemmerasa senang bila 
keberhasilan dicapai adalah jeriah payah diri sendiri namun masih terendah pada merasa senang dengan sebuah kemandirian.

Dari uraian faktor determinan intensi berwirausaha usaha dapat diketahui bahwa keinginan untuk memulai usaha (intensi berwirausaha) bagi mahasiswa terbukti disebabkan oleh budaya belajar, karakteristik individu dan juga pemberian motivasi. Dari ketiga variabel tersebut kontribusinya sebesar 54\%. Kemudian juga variabel karakteristik individu merupakan variabel yang paling berpengaruh dibandingkan dengan variabel budaya belajar dan pemberian motivasi. Intensi berwirausaha juga berpengaruh signifikan terhadap startup usaha yang dilakukan oleh mahasiswa tersebut yakni sebesar $39 \%$.

Hasil penelitian ini sejalan dengan apa yang dikatakan oleh oleh Nurmansyah (2017) bahwa faktor pendidikan dan motivasi; kemudian juga dikatakan oleh Andika, M., \& Madjid, I. (2012) bahwa faktor sikap mahasiswa dalam belajar, norma subjektif dan efikasi diri. Juga disampaikan oleh Astuti, D. A. W. (2009) bahwa faktor konteks keluarga, pekerjaan, pendidikan, hambatan dan dukungan sosial, nilai-nilai individualism serta kolektifitas mempengaruhi intensi berwirausaha mahasiswa. Selain itu juga disampaikan oleh Srimulyani, V. (2013) bahwa kecerdasan adversitas dan juga berkaitan dengan internal locus of control dan juga kematangan karir turut mempengaruhi intensi berwirausaha bagi mahasiswa. Astuti, D. A. W. (2009) menyatakan bahwa intensi berwirausaha berdampak pada starup usaha yang dilakukan mahasiswa. Menurut Andika, M., \& Madjid, I. (2012) norma subjektif sebagai bentuk budaya dalam belajar. Universitas Lancang Kuning menerapkan tujuh nilai unilak yakni: religius, jujur, disiplin, visioner, bertanggungjawab, bermartabat, kerjasama. Kemudian pengaruh intensi berwirausaha juga positif terhadap startupa usaha mahasiswa, dimana pada dasarnya intensi berwirausaha mahasiswa manajemen untuk memulai usahanya sangat tinggi. Dari lima item yang ditanyakan ternyata item tertinggi jatuh pada selalu memiliki rasa ingin tahu yang tinggi setiap melihat seseorang berhasil dalam bisnisnya. Rasa ingin tahu mahasiswa ini mendorong mahasiswa untuk memikirkan usaha apa yang harus mereka rencanakan. Namun mahasiwa masih belum memiliki pengetahuan terhadap ciri sebuah produk dalam bisnis sehingga terkesan produk yang direncanakan adanya kemiripan dengan produk yang lain, hal ini akan menyebakan tidak bertahannya produk dalam menghadapi persaingan.

Dari penjelasan tersebut maka dapat diketahui bahwa mengapa masih rendahnya mahasiswa prodi Manajemen FE Unilak yang tampak memulai usahanya setelah lulus kuliah. Hal ini terbukti 39\% karena intensi berwirausaha (budaya belajar, karakteristik individu dan juga pemberian motivasi). Namun masih terdapat $46 \%$ penyebab lain dari yang ada. Sebagaimana disampaikan oleh Rahman, F. (2017) bahwa perlu penggalian modal manusia dalam berwirausaha.

\section{SIMPULAN}

Simplannya berkaitan dengan hasil penelitian ini antara lain:

1. Terbutki faktor determinan intensi berwirausaha usaha dapat diketahui bahwa keinginan untuk memulai usaha (intensi berwirausaha) bagi mahasiswa terbukti disebabkan oleh budaya belajar, karakteristik individu dan juga pemberian motivasi. Dari ketiga variabel tersebut kontribusinya sebesar $54 \%$. Kemudian juga variabel karakteristik individu merupakan variabel yang paling berpengaruh dibandingkan dengan variabel budaya belajar dan pemberian motivasi.

2. Terbukti bahwa pengaruh intensi berwirausaha juga positif terhadap startup usaha mahasiswa dimana 
intensi berwirausaha juga berpengaruh signifikan terhadap startup usaha yang dilakukan oleh mahasiswa tersebut yakni sebesar $39 \%$, pada dasarnya intensi berwirausaha mahasiswa manajemen untuk memulai usahanya sangat tinggi. Dari lima item yang ditanyakan ternyata item tertinggi jatuh pada selalu memiliki rasa ingin tahu yang tinggi setiap melihat seseorang berhasil dalam bisnisnya. Rasa ingin tahu mahasiswa ini mendorong mahasiswa untuk memikirkan usaha apa yang harus mereka rencanakan. Namun mahasiwa masih belum memiliki pengetahuan terhadap ciri sebuah produk dalam bisnis sehingga terkesan produk yang direncanakan adanya kemiripan dengan produk yang lain, hal ini akan menyebakan tidak bertahannya produk dalam menghadapi persaingan.

\section{DAFTAR RUJUKAN}

Andika, M., \& Madjid, I. (2012). Analisis Pengaruh Sikap, Norma Subyektif dan Efikasi Diri Terhadap Intensi Berwirausaha Pada mahasiswa Fakultas Ekonomi Universitas Syiah Kuala. In Eco-Entrepreneurship Seminar \& Call for Paper" Improving Performance by Improving Environment (pp. 190-196).

Astuti, D. A. W. (2009). Pengaruh Konteks Keluarga, Kerja, Pendidikan, Hambatan Dalam Memulai Bisnis, Dukungan Sosial, Nilai-Nilai Ndividualisme Dan Kolektivisme Pada Intensi Berwirausaha (Studi pada Mahasiswa Jurusan Manajemen Fakultas Ekonomi Universitas Sebelas Maret) (Doctoral dissertation, Fakultas Ekonomi).
Handaru, A. W., Parimita, W., \& Mufdhalifah, I. W. (2015). Membangun Intensi Berwirausaha Melalui Adversity Quotient, Self Efficacy, dan Need For Achievement. Jurnal Manajemen dan Kewirausahaan, 17(2), 165-176.

Nurmansyah, N. (2017). Pengaruh pendidikan kewirausahaan dan motivasi terhadap minat berwirausaha mahasiswa universitas lancang kuning. Jurnal Daya Saing, 3(2), 125-134.

Rahman, F. (2017). Peran Modal Manusia Dan Modal Investasi Terhadap Nilai Produksi Industri Kecil Di Kota Pekanbaru. Jurnal Benefita: Ekonomi Pembangunan, Manajemen Bisnis dan Akuntansi, 2(1), 1-9.

Srimulyani, V. (2013). Analisis pengaruh kecerdasan adversitas, internal locus of control, kematangan karir terhadap intensi berwirauaha pada mahasiswa bekerja. Widya Warta, 1(2), 96-110.

Vemmy, S. C. (2013). Faktor-faktor yang mempengaruhi intensi berwirausaha siswa SMK di Yogyakarta. Jurnal Pendidikan Vokasi, 2(1), 117-125 